\title{
3. Leaders and legitimacy: Lessons from two Labor leadership transitions
}

\author{
Jennifer Rayner
}

In modern Australian political history, few events have generated as much comment and controversy as the sacking of first-term prime minister Kevin Rudd. With its dramatic mid-winter setting and colourful cast of conspirators, Rudd's replacement by his then-deputy, Julia Gillard, captured the public imagination in a way that few other political events have since the Dismissal.

The level of public, media and scholarly attention paid to this event is perhaps not surprising, given at that time only one other Labor prime minister - Bob Hawke - had ever been forced from the party's leadership while still occupying the Lodge. The circumstances surrounding his 1991 replacement by Paul Keating bear many similarities to the more recent political drama: an acrimonious leadership tussle between a popular prime minister and his ambitious deputy, significant global financial uncertainty, and a re-energised and outwardly disciplined Opposition on the attack. Yet the two cases are also distinctly different, as Keating was able to quickly put the leadership issue behind him and move forward to govern for four more years. By contrast, Gillard struggled to shake off questions about her leadership and establish clear authority for her government, before ultimately succumbing to the same party processes that had elevated her to the prime ministership in the first place.

Why was this so? Some have suggested that Gillard's problems have their roots in discomfort with her gender (Hall and Donaghue 2012), or the presidentialstyle election campaign of 2007, which fostered an extreme attachment to Rudd within the Australian electorate (Robinson and Lowe 2012). As Gillard has acknowledged, these factors undoubtedly played some role in the public's response to her as prime minister (Gillard 2013). Close examination of these two cases also demonstrates, however, that there were significant differences in the rhetoric used to communicate and justify these leadership changes to the Australian people, offering an alternative explanation for the origins of Gillard's legitimacy deficit.

As authors such as Christopher Hood (2004), David Zarefsky (2004) and Ronald Krebs and Patrick Jackson (2007) acknowledge, rhetoric is more than verbal window dressing: the way in which public actors describe and define their actions is vital in shaping how the public understands them. Rhetoric constructs meaning by linking real-world events to abstract norms or ideals, providing a 
context and a set of criteria for evaluating such events, and closing off alternative narratives or explanations (Nelson 2004). It is a form of 'persuasive speech' and therefore a 'formidable means of wielding power' (Kane and Patapan 2010). Given its ability to shape public perceptions and mould the public narrative about politics, rhetoric has a direct relationship with political legitimacy, which David Beetham suggests rests upon:

the degree of congruence, or lack of it, between a given system of power and the beliefs, values and expectations that provide its justification ... When we seek to assess the legitimacy of a regime, a political system, or some other power relation, one thing we are doing is assessing how far it can be justified in terms of people's beliefs, how far it conforms to their values or standards, how far it satisfies the normative explanations they have of it. (1991: 11)

In other words, political legitimacy depends - at least in part - upon the public's perception that the exercise of power is 'desirable, proper, or appropriate within some socially constructed system of norms, values, beliefs and definitions' (Suchman 1995: 574). A political leader may possess extensive formal powers and have a range of coercive means at their disposal, but to lead effectively they must also "convince everyone else that they "deserve" to rule and make decisions that influence the quality of everyone's lives ... authorities find governance easier and more effective when a feeling that they are entitled to rule is widespread within the population' (Tyler 2006: 377). As rhetoric is an important tool for constructing and maintaining this perceived right to rule, it should therefore be seen as a fundamental building block of political legitimacy itself.

This chapter explores how Keating and Gillard explained the decision to sack a sitting prime minister and worked to convince the public of their entitlement to the nation's highest elected office. These two events serve as a useful case study because the sudden removal of one leader and their replacement by another would usually be expected to trigger some crisis of legitimacy, but this only appears to have happened in the case of the 2010 leadership spill. The differing fortunes of these two replacement leaders were significantly influenced by differences in rhetoric both leading up to, and at the time of, these leadership transitions. Specifically, where the rhetoric of Keating's rise served to legitimate him as replacement prime minister from the moment of his elevation to the top job, the rhetoric of Gillard's ascension gave the public multiple reasons to question her right to the role. ${ }^{1}$

1 The rhetoric surrounding Gillard's 2013 deposition by Rudd is not discussed here as, at the time of writing, these events were very much still unfolding. 


\section{A tale of two transitions}

The background to the sackings of Hawke and Rudd has been extensively canvassed in both popular and academic works, but it is worth briefly recapping these events to emphasise the parallels between these cases. ${ }^{2}$ Hawke was the Labor hero who returned his party to government in 1983 after the collapse of Gough Whitlam's government and the ensuing eight years of conservative rule, and went on to become Australia's longest-serving Labor prime minister. Throughout his eight years in office Hawke led an ambitious agenda of economic reform, which was primarily conceived and driven by his Treasurer, Paul Keating (Mitchell and Bassanese 2003). The combination of Hawke's populist appeal and Keating's policy nous was hailed as one of the great pairings of modern Australian politics, but it was always balanced on Keating's ambition to be prime minister and the personal tensions this created between the two (Hawke 1994). On two occasions - in 1980 and 1988 - Hawke reportedly promised to hand the leadership over to Keating at an agreed time, but reneged on both deals because he believed that Keating lacked electoral appeal and put policy purity above the interests of working people (Australian Broadcasting Corporation (ABC) 1993: episode 4). Fed up with waiting, Keating launched his first challenge at a meeting of the Australian Labor Party (ALP) Caucus on 3 June 1991, but lost the ballot and spent the next six months on the backbench while a series of political missteps caused Hawke's authority as leader to ebb away (Edwards 1996). On 19 December 1991 Keating mounted a second challenge, and this time defeated Hawke to become Australia's 24th prime minister.

Like Hawke, Rudd was hailed as Labor's messiah after bringing an end to the era of John Howard's conservative government at the 2007 election. 'Kevin 07' and Hawke share the distinction of having the highest personal approval ratings ever recorded by Newspoll (Coorey 2009) and, like Hawke, Rudd embarked on an ambitious reform agenda which encompassed major health, education, Indigenous, environment and communications initiatives. Unlike Hawke, however, Rudd came to Labor politics without a connection to the union movement or the party's factions, and relied on a unity ticket with his deputy, Gillard, to secure Caucus support for his leadership (Wanna 2007). Throughout 2008 and 2009 issues emerged with the implementation of Labor's complex policy agenda, and this led to a decline in both polled support for the party, and Rudd's personal popularity (Stuart 2010). Concerns about the party's electability under Rudd eventually caused members of the ALP's right faction to withdraw

2 For more detailed accounts see d'Alpuget 2010; Hawke 1994; Carew 1992; Edwards 1996; Tanner 2012; McKew 2012; Gordon 1993; Stuart 2010. 
their support for his leadership, and precipitated a formal challenge by Gillard on 23 June 2010 (Coorey 2010). Caucus elected Gillard unopposed and she was sworn in as Australia's first female prime minister on 24 June 2010.

It is indisputable that, on both occasions, the Labor party had the formal power to replace its leader, and that this process was carried out according to established Australian parliamentary convention. It is also true, however, that replacing the nation's highest elected official with little more than a show of hands behind closed doors is an exceptional and contentious move, and one that raised questions about the legitimacy of the replacement leader. The following sections explore three key differences in the rhetoric of these transitions, which may have shaped the perceptions of Keating and Gillard as prime ministers: their prior discussion of desire for the role, their explanation of the reasons for taking it, and the response from the leaders they deposed.

\section{Who wants to be prime minister?}

The first, and perhaps most critical, difference in rhetoric surrounding these transitions was that, where Keating explicitly positioned himself as an alternative prime minister over a period of years leading up to his eventual challenge, Gillard consistently denied that the leadership of her party needed to change - or that she wanted Rudd's job - right up until the evening she replaced him.

Almost since entering the Parliament in 1969, Keating was identified as a potential future prime minister, with big ambitions and a big ego to match (Carew 1992: 2-3). At various points throughout the Labor government's first four terms in office (1983-1990) there were suggestions of an orderly transfer of leadership from Hawke to Keating (Gordon 1993: 76-77; Mills 1993: 214), but as the 1990s unfolded without any sign from the incumbent that he would willingly step aside, Keating began a more active public campaign laying out his claim to the job. This rested upon two pillars. The first was his possession of a big vision for Australia and the capacity to make hard decisions to see it implemented, characteristics that he implied Hawke no longer possessed. The second was the fact that Hawke had publicly anointed him as his successor and privately agreed to hand over the leadership after the 1990 election.

Keating launched the first of these narratives in his leaked speech to the National Press Club in 1990. ${ }^{3}$ Supposedly delivered off the cuff and in an emotional moment following the sudden death of the head of Treasury, Chris Higgins,

3 For a more detailed discussion of this speech and its impact see Carew 1992; Gordon 1993. 
the speech was loaded with such persuasive and evocative language about his vision for Australia and the nature of leadership that it came across as a public application for the nation's highest office. Keating stated:

I think we can do a lot of things better in Australia. Even though this government is ten years old, it's still only scratching the surface of the enormous changes I think Australians will accept and which Australians will embrace ... we're now gathering our pace and we're gathering our people in, and we're a more interesting society and we're well placed in the world. So we have this chance to pull Australia into one of the preferred countries of the nineties and beyond. We really do have this opportunity; it's not beyond us. (1990)

Keating explicitly emphasised that his vision went beyond securing the economic future of Australia - the task that had occupied him as Treasurer and encompassed nothing less than the creation of a wholly modern, wholly independent nation 'that can truly be the envy of the world'. Moving to the question of how Australia would seize the opportunities of this bright new decade, Keating argued:

It just requires a national will and a national leadership to have a go and do it ... leadership is not about being popular. It's about being right and being strong. And it's not whether you go through some shopping centre, tripping over the TV crews' cords. It's about doing what you think the nation requires, making profound judgements about profound issues. (1990)

With this speech, Keating subtly countered long-running suggestions from Hawke and others that he lacked the breadth of vision required from a national leader (Edwards 1996: 391-92). He also presented himself as someone champing at the bit to make that vision a reality, in implied contrast with the ageing Hawke. Furthermore, although Keating never explicitly mentioned Hawke in the speech, his description of the necessary characteristics for leadership clearly favoured himself as someone willing to make 'profound judgements about profound issues', compared with the populist Hawke shaking hands in shopping centres. Similarly, he undermined Hawke's major remaining claim to the prime ministership - his enormous personal popularity - by unfavourably contrasting being popular with 'being right and being strong'. Although Keating subsequently denied that he intended the speech to be a direct challenge to Hawke's leadership, he clearly fired the opening salvo in what turned out to be a year-long march towards the Lodge.

In the lead-up to Keating's first challenge to Hawke in June 1991, he also gave an exclusive live interview on Laurie Oakes's Sunday program, during which he 
returned to the key themes of the Press Club speech and explicitly stated that he could offer renewed leadership in neglected areas such as foreign policy, superannuation and the future design of Australia's cities (Carew 1992: 292). He took pains to frame his challenge to Hawke in terms of the national interest, rather than his personal interest, saying:

I don't resile from the fact that I have personal ambitions but they're nothing like the ambitions I have for Australia. It is the ambitions I've always had for Australia that have kept me running and they still do. I think, obviously, I think I can provide better government. That is, in terms of direction, strategy, esprit de corps, enthusiasm and, dare I say it, where necessary, a touch of excitement. (1991a)

In the interview, Keating also emphasised the second of his claims to the prime minister's role: the fact that Hawke himself had promised to hand it over to him in the now-public Kirribilli agreement of 1988:

I made arrangements with Bob ... for a smooth, effective, sympathetic transition of both leadership and power within the party and to continue to regenerate ideas for the government, and that's what I was hoping would be the case.

The subtext of this interview was the same as that of the Press Club speech: Keating was the man for the future, a new leader for a new decade. This time, however, the contrast with Hawke was overt rather than implied, as Keating outlined the ways he would provide 'better government' and highlighted Hawke's concurrence with the idea of a need for regeneration at the top of the government, as evidenced by the Kirribilli agreement. Collectively, these rhetorical efforts fostered a perception that Keating had a right to lead on the grounds of both expertise and fairness - two criteria that are argued to be important underpinnings of leadership legitimacy (Tost 2010). Significantly, too, this foundation for legitimacy was laid long before Keating actually seized the prime ministership.

By contrast, some of the most vivid and engaging rhetoric employed by Gillard during her political career was used to downplay suggestions that Rudd's leadership was under threat and deny that she had any personal designs on the prime minister's office. As deputy prime minister during the period of Rudd's declining popularity, media speculation naturally turned to Gillard's intentions and the possibility of a challenge to restore the ALP's fortunes. While she initially batted away this speculation with the standard lines about being happy in her current role and having plenty of challenges to meet as deputy, when the speculation showed no sign of dying down, she began to resort to more colourful characterisations. 
In a Sydney radio interview in early May 2010, Gillard denied that there were any moves afoot to replace Rudd, and made an unqualified commitment that she would not be in the prime minister's role by the time of the forthcoming federal election:

Gillard: I'll make the following comments. I always expected that this year as we came into election day we would have a tough, close contest ... so I'm happy to go into that tough, close contest, side by side with Kevin Rudd ...

Interviewer: So will you promise you will not be leader at the next federal election?

Gillard: I can, completely. Neil, this is, you know, it makes good copy for newspapers but it is not within cooee of my day to day reality. You may as well ask me am I anticipating a trip to Mars. No, I'm not, Neil.

Interviewer: After the next election? There's nothing wrong with ambition.

Gillard: I'm ambitious to continue as Deputy Prime Minister doing some very special portfolios I absolutely love.

(Gillard 2010a)

In three separate interviews that month Gillard reiterated this position with increasing exasperation, telling interviewers:

This is all silly hypotheticals. I mean, if Steven Spielberg rang me from Hollywood and asked me to star opposite Brad Pitt in a movie, would I do it? Well, I'd be a little bit tempted. But you know what, I don't reckon Steven Spielberg is going to give me a call. So there's no point worrying about these sorts of hypotheticals. No-one is talking about it so let's not talk about all these fanciful things ...

(Gillard 2010b)

There's more chance of me going round the world sailing solo a dozen times than this chatter in the media becoming anything more than that.

(Gillard 2010c)

There's more chance of me becoming the full-forward for the Dogs than there is any change in the Labor Party.

(Gillard 2010d) 
Gillard's rhetoric went far beyond simply denying that a leadership challenge was ahead; it framed the concept as fanciful and poured scorn on the very idea of her becoming prime minister, making this appear to be a ridiculous proposition. Furthermore, the strong and emphatic nature of her statements particularly her promise that she would not lead the party to the 2010 election - implicitly established a bond of trust between herself and the electorate. In essence, Gillard's language 'painted her into a credibility corner' (Counihan 2010) where any course of action other than remaining as Rudd's deputy would represent a breach of that bond.

Trust is central to political legitimacy (Ruscio 1996) and Margaret Levi(1998) notes that the major means by which political leaders establish their trustworthiness are proven character, demonstrated consistency and encapsulated interest: 'The first requires a presentation of the self that includes a demonstrated willingness to act for principle and against self-interest. Consistency is an indicative measure of trustworthiness, based on the track record of the actor', while encapsulated interest is the willingness of a political actor 'to honour her agreements or to act according to a certain standard' (Levi 1998: 86). Gillard's rhetoric throughout May 2010 conveyed a strong sense that she was willing to put her party and the public interest ahead of her own self-interest. When she then challenged Rudd for the prime ministership, just weeks after making these strong statements of support, she revealed that she lacked consistency and was not, in fact, willing to honour her past commitments. By breaching the public's trust so flagrantly, Gillard demonstrated that she lacked the key quality of trustworthiness, and so placed a significant question mark over the legitimacy of her leadership. While much has been made of her violation of trust over the introduction of a carbon tax, I argue that this initial breach was more significant because it represented the first major fracture in the public's perception of her character.

In short, Keating's rhetoric in the period preceding his challenge to Hawke firmly positioned him as a prime minister-in-waiting with a strong right to lead. By loudly publicising his vision and energy, along with his status as Hawke's chosen successor, Keating laid a strong foundation for his leadership well before he came to office. By contrast, Gillard not only failed to prepare the ground for her leadership in any useful way, she actively discarded one of the critical tools she would need for a successful transition — trust — by emphatically telling the public one thing and then doing the opposite.

\section{Cometh the hour, cometh the (wo)man}

Having positioned themselves differently for the impending leadership transitions, Keating and Gillard also diverged significantly in their rhetoric 
at the moment of their respective ascensions. A comparison of their speeches as prime minister indicates that Keating symbolically embraced his new role from the first moment, while Gillard was more tentative about staking her claim to the nation's top job. Furthermore, where Keating was unapologetic about challenging Hawke for the leadership, and again drew on the language of generational renewal to explain his actions, Gillard presented herself as a reticent conscript to the role, one spurred into action only because the Rudd government had 'lost its way'.

Speaking to the Canberra press gallery immediately after winning the party room ballot, Keating briefly paid tribute to Hawke before launching into a direct dialogue with the Australian electorate. He began:

In my first words as Prime Minister-elect to you, the Australian people, I want to make three commitments. The first is I pledge to give everything I've got to the job and the country. The second is to deal honestly with the people, to tell them the truth. In tough times the temptation is always to gild the lily. I'll be resisting that temptation as much as possible. I'll speak honestly with them, realistically, and I'll listen accordingly. The third commitment is that I pledge to fight the battle against unemployment and for economic recovery with all the energy I can muster. (1991b)

In the space of a single paragraph, Keating explicitly claimed the mantle of prime minister and set the tone for his leadership: frank, focused, pulling no punches. By addressing himself directly to 'the Australian people', describing himself as the 'Prime Minister-elect' and making a series of commitments about his dedication and commitment to serve, he subtly mirrored the traditional tropes of an election-night victory speech and so presented himself in the triumphantyet-humble mould of a newly elected leader. This language dispels from the outset any suggestion that Keating was less than a rightful prime minister.

In driving home his reasons for taking over the reins of leadership, Keating reiterated the themes that had formed the basis of his claim since his 1990 speech to the Press Club:

This period gives us great opportunities and the '90s hold for Australia very great promise indeed ... I believe the Australian people are looking both for hope and direction for the 1990s and this country can be in a very good position in the 1990s, notwithstanding the fact we've got a recession ... We can be well set up in the 1990s and I believe I can play a role in that and that's why I believe that I will serve the Labor Party well. (Keating 1991b) 
Keating's invocation of 'hope and direction' is a direct reference to his earlier musings on the purpose of leadership and highlights his emphasis on leading from the front; in implied contrast with Hawke's famously consensual, populist leadership style. His repeated invocation of 'the 1990s' further serves to underline his focus on the times ahead and so solidifies the self-perpetuated account of him as a leader for the future, while also drawing a symbolic line under Hawke's leadership, which belonged to the previous decade. In case his audience was in any way unclear about Keating's intention to move beyond Hawke's legacy and forge his own path, the new prime minister went on to state this explicitly:

Bob and I conducted a government which contained two leaders. And we worked as a good team for a very long period of time ... but, time tells ... I think that the need for policy shifts, that dexterity I mentioned earlier, and generational change is important. I think it is important for a political party to change itself. (Keating 1991b)

This statement also served a useful purpose in subtly reminding listeners of Keating's other significant claim to the prime ministership: his status as Hawke's chosen successor. While he did not explicitly invoke the Kirribilli agreement or Hawke's past commitments to him, the interlinked references to his partnership with Hawke and 'generational change' implicitly frame the transition in this light.

In all, the overwhelming impression conveyed by Keating's first speech as Prime Minister is that he was firmly in control of the ship of state and had already begun steering it on a new course, which had long been charted in his mind. Keating's rhetoric brooked no challenge to his right to lead and acknowledged no doubt that the moment called for a leader such as him. And so, by appearing as a legitimate prime minister, Keating became one.

By contrast, Gillard's first speech after accepting her party's nomination as prime minister offered a qualified account of her claim to the job and raised significant questions about both her commitment and capacity to lead. The speech appears designed to head off criticism about Rudd's deposition and minimise perceptions that Gillard had acted dishonourably or disloyally, but by directly acknowledging these negatives, Gillard inadvertently gave them weight and credibility.

In contrast with Keating's bold opening, Gillard started her speech by saying:

It's with the greatest humility, resolve and enthusiasm that I sought the endorsement of my colleagues to be the Labor leader and to be the Prime Minister of this country. I have accepted that endorsement. I am truly honoured to lead this country which I love. (2010e) 
She went on to give an extended outline of her guiding beliefs in education, family, hard work and fairness before stating:

It is these beliefs that have been my compass during the 3.5 years of the most loyal service I could offer to my colleague, Kevin Rudd. I asked my colleagues to make a leadership change because I believed that a good government was losing its way ... I love this country and I was not going to sit idly by and watch an incoming opposition cut education, cut health and smash rights at work. My values and my beliefs have driven me to step forward to take this position as Prime Minister. (2010e)

Where the public may have expected to see Gillard trumpet her historic status as Australia's first female prime minister, in fact her opening remarks framed the leadership transition primarily as a changing of personnel within the Labor Party, with the associated change in the nation's leadership presented more as a necessary consequence of this than the purpose of the exercise. Furthermore, her eagerness to share the responsibility for replacing Rudd with the parliamentary caucus, and her reticence to directly describe herself as the prime minister, conveyed the impression that Gillard felt uneasy about the manner of her rise.

Gillard's statement that she had provided 'loyal service' to Rudd but could not 'sit idly by' and watch the government lose its way was clearly intended to create a narrative bridge between her statements of the preceding months and her actions on the evening of the challenge. It invited her audience to believe that she had been genuine in her support for Rudd up to some unspecified tipping point, and asked them to see her as a dutiful, capable foot soldier stepping forward with a heavy heart to take the reins from a floundering commander. In reality, however, her remarks served to emphasise both the brief nature of Rudd's tenure as leader and her prominent role in the government that had 'lost its way'. Gillard acknowledged this latter point a moment later in saying:

I take my fair share of responsibility for the Rudd Government's record, for our important achievements and errors made. I know the Rudd Government did not do all it said it would do. And at times, it went off track. (2010e)

Although perhaps intended to portray Gillard as humble and realistic about the government's failings, this statement invited unflattering questions about her own fitness for the leadership for, if she was part of the problem, how could she be trusted to lead the search for solutions? And, if she had been there, working alongside Rudd while mistakes were made, why did he have to leave while she got to lead? The remainder of Gillard's speech offered no answer to these questions, leaving them to fester in the minds of the Australian public. 
While Gillard's first comments failed to strike a confident or persuasive note, these rhetorical failings were hardly fatal. It could be argued, however, that her next remarks proved to be, because they explicitly linked the legitimacy of her leadership to the upcoming federal election result. Gillard stated:

I also certainly acknowledge that I have not been elected Prime Minister by the Australian people. And in the coming months I will ask the GovernorGeneral to call for a general election so that the Australian people can exercise their birthright to choose their Prime Minister. Between now and this election, I seek their consideration and support. (2010e)

This is a curious statement from a prime minister-elect, as there is nothing in Australia's system of parliamentary democracy which requires that leaders be elected by 'the people', nor does any mechanism exist for them to actually exercise what Gillard calls 'their birthright' - two facts of which she would have been undoubtedly aware. Her remarks appear calculated to head off public criticism about the secretive and autocratic manner of Rudd's removal by emphasising her commitment to democratic ideals. They are also a direct response to Rudd's assertions about the illegitimacy of her challenge (discussed below). By promoting this inaccurate characterisation of a prime ministerial mandate as deriving from the people, and specifically describing herself as an unelected leader, Gillard in fact implied what many in her audience may have been thinking: that she did not have a rightful claim to the role. Furthermore, by emphasising the importance of elections in conferring such a rightful claim, Gillard implicitly positioned her leadership as contingent upon winning that poll. This was underlined by her commitment - under questioning from the media - not to move into the Lodge until she had been elected in her own right, as she stated: 'I believe it is appropriate for me to stay [in Melbourne] until we have an election and I have fulsomely earned the trust of the Australian people to be prime minister.' (2010e)

In other words, Gillard eschewed the language of parliamentary democracy which would have provided a ready-made rationale for the challenge and her leadership - in favour of appeals to direct, popular democracy. This may not have posed a lasting problem if she had indeed won the 2010 poll outright, but given the election resulted in Australia's first hung parliament and minority government since the 1940s, this decision arguably created a fundamental and enduring weakness at the core of Gillard's prime ministership. Some have gone so far as to suggest that the low level of support for Labor at the 2010 election can be interpreted as an attempt by the voters of Australia to deny Gillard the win she needed to truly legitimate her leadership (Thampapillai 2010).

As though explicitly linking the legitimacy of her leadership to an electoral mandate was not problematic enough, Gillard also used this first speech to 
commit herself to solving a number of specific problems that had arisen during the Rudd administration. These ranged across some of the policy areas most closely associated with Rudd's 2007 election pitch for office, and included: 'establish[ing] a community consensus for action' on climate change, negotiating 'a fairer share of our inheritance, the mineral wealth that lies in our grounds', and 'bringing the Budget back in surplus'. Although praising Rudd, Gillard distinguished herself from him as a leader who would prioritise results over rhetoric in these areas, saying: 'Ultimately, Kevin and I disagreed about the direction of the government. I believed we needed to do better' (Gillard 2010e). By singling out these areas of high-profile policy failure, Gillard presumably intended to underline why a change of leadership was necessary and set out her immediate priorities for action in the months ahead. In specifically committing to succeed where Rudd had failed, however, Gillard made her leadership contingent upon 'doing better' than the former prime minister. As Gillard should have realised, the danger of linking her claim to the role to an ability to deliver better policy outcomes was that any perceived failure to do so would implicitly diminish her right to lead. This is arguably what happened throughout 2011 and 2012, and helps to explain why Gillard's policy stumbles almost always led to speculation about the security of her leadership during her term as prime minister (see, for example, Pearson 2011; Taylor 2012).

Comparing Keating's and Gillard's first speeches as prime minister reveals that the two could not be more different in their tone, content, symbolism and subtext. Keating's was clearly a victory speech — one delivered by a man who had long worked to demonstrate his credentials to be prime minister, who believed in the strength of his claim to the role, and who was impatient to begin wielding the power that was rightfully his. Keating's rhetoric left no room for doubt or ambiguity about the fitness of his rise to the nation's highest elected office, and so helped him to appear as a legitimate leader from the first moment of his prime ministership. By contrast, Gillard's speech was part justification, part apology and part bargain. It raised unanswered questions about her right to lead and shackled her fate to a range of events beyond her direct control and, in doing so, fostered an enduring legitimacy deficit which dogged her to the end. It must be assumed that this was the unintended result of poor rhetorical choices and a lack of strategic foresight, rather than a deliberate effort by Gillard, for it seems unlikely that any leader would wilfully hobble their own fortunes as comprehensively as she appears to have done.

\section{The view of the vanquished}

Finally, examination of the rhetoric of the two leaders who were deposed by Keating and Gillard indicates how their accounts of these events boosted or 
diminished the legitimacy of their successors. For the most part, Hawke and Rudd stuck closely to the script expected of former leaders - thanking their colleagues and the nation for the opportunity to serve, highlighting their achievements, and wishing the new leader well (see, for example, ABC 1993; Mills 1993: 288-95; Rudd 2010b). They diverged specifically and significantly, however, in their language describing the party room challenge against them: Hawke professed to respect his colleagues' judgement and the validity of their decision to change leaders, while Rudd denied his party's right to do so by invoking the idea of a popular mandate. Where Hawke's rhetoric supported Keating's perceived right to lead, Rudd's effectively (and presumably deliberately) undercut Gillard's efforts to establish herself as his legitimate replacement.

In the immediate aftermath of his sacking, Hawke declined to comment on the leadership spill and focused instead on cementing his legacy as 'a bloke who loved his country, still does, and loves Australians, and who was not essentially changed by high office' (Mills 1993: 294). He broke his silence in a broadcast television interview some weeks later however, telling the nation that he was 'hurt' by his colleagues' decision to replace him, but that they would not find him criticising them for doing so:

Interviewer: Was the action in dumping you, fair?

Hawke: Well, the Caucus has always got the right to make the decision about leadership. They have always got that right.

Interviewer: I didn't ask you about right though — fair.

Hawke: Well, whether people exercise - if people have a right, you can hardly say that they shouldn't exercise it. I have thoughts about how it was done ... [but] I don't think right now is the time to open up on that.

Interviewer: Well, was it a just decision?

Hawke: Well, in politics, in the end, it's numbers that count ... it was very tight, but in the end, the numbers were there.

(Hawke 1992)

This is an important statement because Hawke explicitly positioned his deposition in the context of Australian parliamentary convention, and emphasised that the ALP had simply exercised a long-established right. Even when pressed by the interviewer to make a distinction between the act being 'right' and 'fair', Hawke insisted that his party had acted within their powers and emphasised Keating's valid win in the party ballot process. 
Hawke's magnanimity is in sharp contrast with Rudd's rhetoric on the evening of Gillard's challenge. Admittedly, Rudd was speaking in the heat of the moment rather than with the benefit of time for reflection, but his strident remarks framed the change of leadership as a direct challenge to democracy itself and a deliberate subversion of the Australian people's will. Speaking live to the nation with all the symbolic splendour of the prime minister's suite behind him, Rudd said:

I was elected by the people of Australia as Prime Minister of Australia. I was elected to do a job, I intend to continue doing that job ... I was not elected by the factional leaders of Australia, of the Australian Labor Party, to do a job - though they may be seeking to do a job on me, that's a separate matter. The challenge therefore is to honour the mandate given to me by the Australian people. (2010a)

The suggestion that Rudd was elected by 'the people of Australia' or was in possession of a mandate given by them is a falsehood. Given Rudd's famed attention to detail, his use of such misleading rhetoric can only be seen as a deliberate attempt to frame Gillard as a usurper and delegitimise the internal party processes then underway. Rudd's relationship with the Australian electorate had always been his primary source of power - first as Opposition leader, and later as prime minister — so it is perhaps not surprising that he would fall back on this at a moment of crisis (Wilson 2013). But what is surprising is the extent to which his rhetoric appears to have influenced the following discussion of these events. Countless media organisations echoed the spirit of his remarks in describing Gillard's challenge as a 'coup', a 'putsch' and a power grab by the ALP's 'faceless men' (see, for example, Benson 2010; Kenny 2010; Rodgers 2010; Santow 2010; Coorey 2010). As previously discussed, even Gillard herself adopted Rudd's characterisation of the situation, by acknowledging that she lacked an electoral mandate and asking Australians for their forbearance until she could obtain one. Of course, he could not have anticipated that she would tie her fortunes so directly to the idea of an electoral mandate or that this would work out as poorly as it did for her. But it could certainly be argued that Rudd sowed the seeds for these later events - and so contributed to Gillard's legitimacy deficit - by effectively shaping the criteria that would be used to assess her right to lead.

Hawke and Rudd's contributions suggest that the rhetoric of the vanquished can play an important role in influencing perceptions of the victor. By presenting his sacking as a valid exercise of the party's right to choose its leader, Hawke confirmed that Keating had a legitimate claim to the prime ministership. Rudd's rhetoric achieved entirely the opposite effect as, by denying his party's right to choose in the first place, he undermined the legitimacy of their chosen leader - Gillard. 


\section{Lessons from (for?) Labor}

Sacking a sitting prime minister is a rare and extreme act, and it is tempting to view such acts as isolated incidents without any wider lessons to offer. But this discussion of the Hawke/Keating and Rudd/Gillard transitions suggests that there are indeed important insights to be gained from comparing these events.

If we return to the idea that political legitimacy rests upon the public's perception that the exercise of power is 'desirable, proper, or appropriate within some socially constructed system of norms, values, beliefs and definitions' and that those in power 'deserve to rule', it is clear that the rhetoric of Keating's rise actively promoted such perceptions. By contrast, the rhetoric surrounding Gillard's ascension fostered, at best, a qualified sense of her right to the role and, at worst, outright denial that she possessed any such right. This chapter's core argument is that their differing fortunes as prime minister can be traced - at least in part - to this essential fact.

This highlights two important things about political rhetoric. Firstly, it emphasises the point that rhetoric is part of the foundation upon which political legitimacy is built. Studies of rhetoric often focus on how political leaders wield this as a persuasive tool when governing (see, for example, Masters and 't Hart 2012; Roncarolo 2005; Wood 2007), but the Keating and Gillard cases remind us that rhetoric is also critical for establishing a leader's right to govern in the first place; it is a tool for creating leadership as much as exercising it. If a political leader cannot persuade the public of their essential legitimacy, then they will lack the authority and autonomy to lead - as Gillard arguably experienced throughout her three years in office. Rhetoric builds political legitimacy and, in doing so, can help make or break political leaders.

Secondly, the Keating and Gillard cases emphasise the different outcomes that can be achieved with the calculated use of rhetoric, as compared with rhetoric that is ad hoc or inconsistent. An important factor in the success of Keating's rhetorical approach was his ability to develop a compelling and coherent message, and then deploy this consistently at key moments to build his perceived legitimacy as a replacement prime minister. Similarly, our discussion highlights how Gillard weakened her own perceived legitimacy through a lack of strategic foresight about the possible consequences of her rhetorical choices. Given that political rhetoric often forms part of an ongoing dialogue with the public, it makes sense that perceptions of legitimacy will be boosted when individual speech acts can be integrated into a broader, coherent narrative about the leader and their leadership, or diminished when it cannot. Rhetoric, then, is a tool to be wielded strategically to construct a sound foundation for leadership. 
These insights come too late to be of use to former prime minister Julia Gillard, but future leadership aspirants would certainly do well to consider them. For scholars of Australian politics and the wider field of political leadership, these cases emphasise the point that rhetoric constructs political outcomes even as it seeks to explain or embellish them, and is therefore an important focus for ongoing study.

\section{References}

Australian Broadcasting Corporation (ABC) 1993. Episodes 4 and 5. Labor in Power. DVD. ABC Television News and Current Affairs Documentary Unit, Sydney.

Anderson, D.G. 1988. Power, rhetoric and the state: A theory of presidential legitimacy. The Review of Politics 50(2): 198-214.

Beetham, D. 1991. The legitimation of power. London: Macmillan.

Benson, S. 2010. Why a coup was on the menu for Gillard. Daily Telegraph 25 June: 10.

Carew, E. 1992. Paul Keating: Prime minister. Sydney: Allen \& Unwin.

Coorey, P. 2009. The Rudd supremacy. Sydney Morning Herald 30 March. URL: http://www.brisbanetimes.com.au/national/the-rudd-supremacy-200903309g6s.html. Consulted 8 January 2013.

- 2010. The faceless men who conspired to bring down the Prime Minister. Sydney Morning Herald 24 June. URL: http://www.smh.com.au/national/thefaceless-men-who-conspired-to-bring-down-the-prime-minister-20100623yz8u.html. Consulted 2 February 2013.

Counihan, B. 2010. Gillard gets creative in ducking the leadership question. Sydney Morning Herald 18 May. URL: http://www.smh.com.au/federalpolitics/political-opinion/gillard-gets-creative-in-ducking-the-leadershipquestion-20100518-va4d.html. Consulted 10 February 2013.

d'Alpuget, B. 2010. Hawke: the prime minister. Carlton: Melbourne University Press.

Edwards, J. 1996. Keating: The inside story. Ringwood: Penguin Books Australia.

Gillard, J. 2010a. Interview with Neil Mitchell. Radio 3AW 10 May. URL: http:// ministers.deewr.gov.au/gillard/radio-interview-3aw. Consulted 2 August 2013. 
2010b. Interview with Fairfax Media 12 May. URL: http://media. nationaltimes.com.au/opinion/national-times/gillard-id-act-with-brad-butwont-take-the-lead-1444007.html. Consulted 2 August 2013.

2010c. Interview with Chris Smith. Radio 2GB 15 May. URL: http:// ministers.deewr.gov.au/gillard/radio-interview-2gb-afternoonshow. Consulted 2 August 2013.

2010d. Ministerial press conference, Brisbane. 18 May. URL: http://parlinfo.aph.gov.au/parlinfo/search/display/display.w3p;adv =yes; orderBy=customrank; page =0; query=Author $\% 3$ AGillard $\% 20$ Date \%3A17\%2F05\%2F2010\%20\%3E\%3E\%2018\%2F05\%2F2010\%20 Dataset $\% 3$ Apressrel;rec=5;resCount=Default. Consulted 2 August 2013.

2010e. Joint press conference with Deputy Prime Minister Wayne Swan, Parliament House, Canberra. 24 June. URL: http://pmtranscripts.dpmc.gov. au/browse.php?did=17511. Consulted 2 August 2013.

2013. Statement by the former Prime Minister, the Hon. Julia Gillard. 26 June. URL: http://parlinfo.aph.gov.au/parlInfo/search/display/display.w3 p;adv=yes;orderBy=customrank;page $=0 ;$ query $=$ Author $\% 3$ AGillard $\% 20$ Date \%3A25\%2F06\%2F2013\%20\%3E\%3E\%2027\%2F06\%2F2013\%20 Dataset $\% 3$ Apressrel;rec=4;resCount=Default. Consulted 2 August 2013.

Gordon, M. 1993. A question of leadership. Paul Keating: Political fighter. St Lucia: University of Queensland Press.

Hall, L.J. and Donaghue, N. 2012. 'Nice girls don't carry knives': Constructions of ambition in media coverage of Australia's first female prime minister. British Journal of Social Psychology: 1-17.

Hawke, B. 1994. The Hawke memoirs. Port Melbourne: William Heinemann Ltd. 1992. Interview with Mike Willesee. A Current Affair 6 January. URL: http:// parlinfo.aph.gov.au/parlInfo/search/display/display.w3p;adv=yes;orderB $\mathrm{y}=$ customrank; page $=0$; query $=$ Autho $\quad$ rSpeakerReporter $\% 3$ AHawke $\% 20$ Date \%3A01\%2F01\%2F1992\%20\%3E\%3E\%2007\%2F01\%2F1992\%20Da taset $\% 3$ Aemms,radioprm,tvprog;rec $=1 ;$ resCount=Default. Consulted 31 January 2013.

Hood, C. 2004. The art of the state. Culture, rhetoric and public management. 2nd edition. New York: Oxford University Press.

Kane, J. and Patapan, H. 2010. The artless art: Leadership and the limits of democratic rhetoric. Australian Journal of Political Science 45(3): 371-89. 
Keating, P. 1990. Doing the Placido Domingo. In M. Fullilove ed. Men and Women of Australia: our greatest modern speeches. Milsons Point: Random House Australia.

1991a. Interview with Laurie Oakes. Sunday Program 2 June. URL: http:// parlinfo.aph.gov.au/parlInfo/search/display/display.w3p;adv=yes;orderB $\mathrm{y}=$ customrank; page $=0$; query $=$ AuthorSpeakerReporter $\% 3$ AKeating $\% 20$ Date \%3A01\%2F06\%2F1991\%20\%3E\%3E\%2003\%2F06\%2F1991\%20 Dataset $\% 3$ Aemms,radioprm,tvprog;rec=8;resCount=Default. Consulted 31 January 2013.

1991b. Press Conference, Parliament House, Canberra. 19 December. URL: http://pmtranscripts.dpmc.gov.au/browse.php?did=8367. Consulted 31 January 2013.

Kenny, M. 2010. A lightning and very Labor coup. Adelaide Advertiser 25 June: 2.

Krebs, R.R. and Jackson, P.T. 2007. Twisting tongues and twisting arms: The power of political rhetoric. European Journal of International Relations 13(1): 35-66.

Levi, M. 1998. A state of trust. In V.A. Braithwaite and M. Levi eds. Trust and governance. New York: Russell Sage Foundation.

Masters, A. and 't Hart, P. 2012. Prime ministerial rhetoric and recession politics: Meaning making in economic crisis management. Public Administration 90(3): 759-80.

McKew, M. 2012. Tales from the political trenches. Carlton: Melbourne University Press.

Mills, S. 1993. The Hawke years: The story from the inside. Ringwood: Viking.

Mitchell, A. and Bassanese, D. 2003. Economic reform: A barrel of thrills and spills. In S. Ryan and T. Bramston eds. The Hawke government. A critical retrospective. North Melbourne: Pluto Press.

Nelson, T.E. 2004. Policy goals, public rhetoric and political attitudes. The Journal of Politics 66(2): 581-605.

Pearson, C. 2011. Carbon tax calls Gillard's leadership into question. Australian 23 April: 10.

Robinson, G. and Lowe, D. 2012. Rudd's presidential politics vs Gillard's Westminster wisdom: Who will win out in the style battle? The Conversation 24 February. 
Rodgers, E. 2010. Swan denies factions knifed Rudd. ABC News Online 25 June. URL: http://www.abc.net.au/news/2010-06-25/swan-denies-factionsknifed-rudd/880824. Consulted 8 February 2013.

Roncarolo, F. 2005. Campaigning and governing: An analysis of Berlusconi's rhetorical leadership. Modern Italy 10(1): 75-93.

Rudd, K. 2010a. Leadership challenge announcement speech, Parliament House, Canberra. 23 June. URL: http://www.adelaidenow.com.au/news/transcriptof-prime-minister-rudds-speech/story-e6frea6u-1225883458033. Consulted 2 February 2013.

2010b. Farewell speech, Parliament House, Canberra. 24 June. URL: http://www.theaustralian.com.au/in-depth/full-transcript-of-kevin-ruddsfarewell-speech/story-fn5vfgwx-1225883796571. Consulted 2 February 2013.

Ruscio, K.P. 1996. Trust, democracy and public management: A theoretical argument. Journal of Public Administration Research and Theory 6(3): 461-77.

Santow, S. 2010. Faceless men install new PM. The World Today 24 June.

Stuart, N. 2010. Rudd's way. November 2007 - June 2010. Carlton: Scribe.

Suchman, M.C. 1995. Managing legitimacy: Strategic and institutional approaches. Academy of Management Review 20(3): 571-610.

Tanner, L. 2012. Politics with purpose. Occasional observations on public and private life. Melbourne: Scribe Publications.

Taylor, L. 2012. Policy holds fate of political futures. Newcastle Herald 30 June: 3.

Thampapillai, D. 2010. Democratic legitimacy in the Gillard period. Online Opinion. URL: http://www.onlineopinion.com.au/view.asp?article $=10896$. Consulted 6 February 2013.

Tost, L.P. 2010. The psychology of legitimacy: Implications for organisational leadership and change. Durham: Duke University.

Tyler, Tom R. 2006. Psychological perspectives on legitimacy and legitimation. Annual Review of Psychology 57: 375-400.

Wanna, J. 2007. Political chronicles: Commonwealth of Australia July to December 2006. Australian Journal of Politics and History 53(2): 281-88.

Wilson, J. 2013. Kevin Rudd, celebrity and audience democracy in Australia. Journalism: Theory, Practice \& Criticism. Online first edition 17 June 2013. URL: http://jou.sagepub.com/content/early/2013/06/13/1464884913488724. Consulted 10 July 2013. 
Wood, B.D. 2007. The politics of economic leadership: Causes and consequences of presidential rhetoric. Princeton: Princeton University Press.

Zarefsky, D. 2004. Presidential rhetoric and the power of definition. Presidential Studies Quarterly 34(3): 607-19. 
This text taken from Studies in Australian Political Rhetoric, Edited by John Uhr and Ryan Walter, published 2014 by ANU Press, The Australian National University, Canberra, Australia. 